\title{
Prevalence and Clinical Characteristics of Recently Diagnosed Type 2 Diabetes Patients with Positive Anti- Glutamic Acid Decarboxylase Antibody
}

\author{
Yul Hwangbo ${ }^{1}$, Jin Taek Kim², Eun Ky Kim ${ }^{1}$, Ah Reum Khang ${ }^{1}$, Tae Jung Oh ${ }^{1}$, Hak Chul Jang ${ }^{1}$ Kyong Soo Park ${ }^{1}$, \\ Seong Yeon Kim ${ }^{1}$, Hong Kyu Lee ${ }^{2}$, Young Min Cho ${ }^{1}$ \\ ${ }^{1}$ Department of Internal Medicine, Seoul National University College of Medicine, \\ ${ }^{2}$ Department of Internal Medicine, Eulji General Hospital, Seoul, Korea
}

\begin{abstract}
Background: Latent autoimmune diabetes in adults (LADA) refers to a specific type of diabetes characterized by adult onset, presence of islet auto-antibodies, insulin independence at the time of diagnosis, and rapid decline in $\beta$-cell function. The prevalence of LADA among patients with type 2 diabetes varies from $2 \%$ to $20 \%$ according to the study population. Since most studies on the prevalence of LADA performed in Korea were conducted in patients who had been tested for anti-glutamic acid decarboxylase antibody (GADAb), a selection bias could not be excluded. In this study, we examined the prevalence and clinical characteristics of LADA among adult patients recently diagnosed with type 2 diabetes.

Methods: We included 462 patients who were diagnosed with type 2 diabetes within 5 years from the time this study was performed. We measured GADAb, fasting insulin level, fasting C-peptide level, fasting plasma glucose level, HbA1c, and serum lipid profiles and collected data on clinical characteristics.

Results: The prevalence of LADA was 4.3\% (20/462) among adult patients with newly diagnosed type 2 diabetes. Compared with the GADAb-negative patients, the GADAb-positive patients had lower fasting C-peptide levels $(1.2 \pm 0.8 \mathrm{ng} / \mathrm{mL}$ vs. $2.0 \pm 1.2$ $\mathrm{ng} / \mathrm{mL}, P=0.004)$. Other metabolic features were not significantly different between the two groups.

Conclusion: The prevalence of LADA is $4.3 \%$ among Korean adult patients with recently diagnosed type 2 diabetes. The Korean LADA patients exhibited decreased insulin secretory capacity as reflected by lower C-peptide levels.
\end{abstract}

Keywords: Diabetes mellitus, type 1; Diabetes mellitus, type 2; Glutamate decarboxylase

\section{INTRODUCTION}

Type 1A diabetes mellitus is caused by the autoimmune destruction of pancreatic $\beta$-cells, which leads to insulin deficiency resulting in a need for insulin therapy for most patients. Pancreatic auto-antibodies, such as islet cell cytoplasmic antibody (ICA) [1], glutamic acid decarboxylase antibody (GAD$\mathrm{Ab}$ [2], and antibodies to the protein tyrosine phosphatases IA- 2 or IA-2 $\beta$, are used to diagnose type $1 \mathrm{~A}$ diabetes [3]. However, as in typical cases of type $1 \mathrm{~A}$ diabetes, some patients clin- ically diagnosed with type 2 diabetes have circulating auto-antibodies to pancreatic $\beta$-cells [4-7]. Type 2 diabetes with positive auto-antibodies is characterized by insulin independence at the time of diagnosis, a high incidence of relative insulin deficiency and rapid progression to insulin dependence [5-9]. This form of diabetes has also been called latent autoimmune diabetes in adults (LADA) [8], slowly progressive insulin-dependent diabetes mellitus [10] or type 1.5 diabetes [11]. LADA has been included in the proposal for the World Health Organization (WHO) criteria for diabetes as a subgroup of type 1 dia-
Corresponding author: Young Min Cho

Department of Internal Medicine, Seoul National University College of

Medicine, 101 Daehak-ro, Jongno-gu, Seoul 110-744, Korea

E-mail: ymchomd@snu.ac.kr

Received: Aug. 11, 2011; Accepted: Oct. 21, 2011
This is an Open Access article distributed under the terms of the Creative Commons Attribution Non-Commercial License (http://creativecommons.org/licenses/by-nc/3.0/) which permits unrestricted non-commercial use, distribution, and reproduction in any medium, provided the original work is properly cited. 
betes [12].

In the United Kingdom Prospective Diabetes Study (UKPDS), $10 \%$ of patients were positive for GADAb, and $52 \%$ of patients with a titer of GADAb $\geq 20 \mathrm{U} / \mathrm{L}$ required insulin treatment within 6 years after diagnosis [7]. Fourlanos et al. [13] found that LADA was commonly associated with the following clinical features: age of onset $<50$ years, acute onset of symptoms, body mass index (BMI) $<25 \mathrm{~kg} / \mathrm{m}^{2}$, and personal history or family history of autoimmune diseases.

There is a controversy about whether LADA can be viewed as a separate form of diabetes or rather a subgroup of type 1 diabetes [14]. Patients with LADA have a similar disease process as patients with type 1 diabetes in that they have a higher rate of progression to insulin dependency and a lower prevalence of metabolic syndrome $[15,16]$. However, LADA exhibits a slower progression toward insulin dependency compared to typical type 1 diabetes and also shows clinical features of insulin resistance. Recent studies reported that LADA shares genetic features of both type 1 and type 2 diabetes $[17,18]$. Therefore, LADA is considered a specific form of diabetes that lies somewhere between type 1 and type 2 diabetes [18].

In Korea, several studies have examined the prevalence and clinical characteristics of LADA [19-24]. However, the number of patients in most of these studies was small, and the study patients were tested for GADAb probably due to suspicion of a diagnosis other than type 2 diabetes. Thus, these studies had a limitation to represent the prevalence or clinical characteristics of LADA in Koreans. In this study, we measured GADAb in patients with recent onset type 2 diabetes and evaluated the prevalence of GADAb positivity and compared the clinical characteristics of patients with and without GADAb.

\section{METHODS}

\section{Participants}

This study was approved by the Institutional Review Board of Seoul National University Hospital (H-1106-127-369). Between January 2005 and July 2007, we tested GADAb in 749 patients over 20 years of age who first visited the Diabetes Clinic of Seoul National University Hospital. We selected 527 patients who were diagnosed with diabetes within the past 5 years and excluded patients with type 1 diabetes, those who started insulin therapy within 1 year after diagnosis of diabetes, and patients with a history of diabetic ketoacidosis. We also excluded patients who were pregnant, had chronic liver disease, acute infection, history of organ transplantation, current chemotherapy for malignancy, or other conditions that could affect glucose metabolism. Therefore, a total of 462 patients were included in the analysis.

\section{Methods \\ GADAb test}

GADAb was measured by a radioimmunoassay employing ${ }^{125}$ I-labeled human recombinant GAD65 manufactured by RSR (Cardiff, Wales, UK). GADAb values $>1.0 \mathrm{U} / \mathrm{mL}$ were considered positive.

\section{Laboratory methods}

Biochemical tests (such as serum levels of glucose and lipids) were measured with the Toshiba 200FR Neo Chemistry autoanalyzer (Toshiba Medical Systems Co., Tokyo, Japan) after overnight fasting. Hemoglobin Alc (HbAlc) was determined by an affinity chromatography (Bio-Rad Laboratories, Hercules, CA, USA), and the C-peptide level was evaluated with a radioimmunoassay (TFB, Tokyo, Japan). The serum insulin concentration was measured using a immunoradiometric assay (Biosource Europe S.A., Nivelles, Belgium). Insulin resistance and $\beta$-cell function were estimated using homeostasis model assessment (HOMA-IR and HOMA- $\beta$, respectively) [25].

\section{Physical examination}

We measured height, weight, and blood pressure with standard methods. The waist circumference across the area midway between the lowest rib margin and the highest point of the iliac crest and the hip circumference across the widest level over both the greater trochanters were measured.

\section{Statistical analysis}

Statistical analyses were performed using the SPSS (SPSS Inc., Chicago, IL, USA). Data are given as the mean \pm standard deviation. $\chi^{2}$-test, Fisher's exact test, Student's $t$-test, and MannWhitney $U$ test were used where appropriate. A two-tailed $P$ value less than 0.05 was considered statistically significant.

\section{RESULTS}

\section{Prevalence of GADAb positivity}

Of 462 patients, 20 (4.3\%) were positive for GADAb. The GADAb positivity among men and women was $4.6 \%(12 / 260)$ 


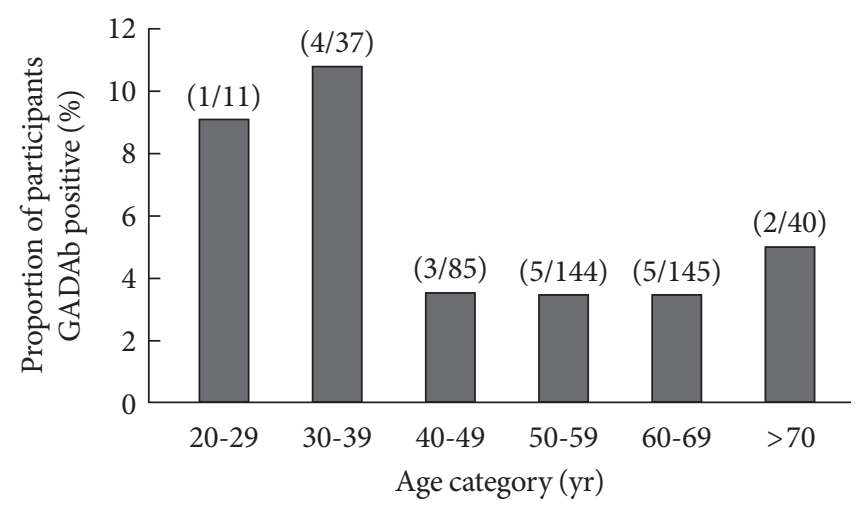

Fig. 1. The prevalence of glutamic acid decarboxylase antibody (GADAb)-positivity per age group. GADAb was found in $9 \%$ to $10 \%$ of patients in their 20 s or 30 s, whereas it was identified in less than $5 \%$ of patients older than 40 years.

and $4.0 \%(8 / 202)$, respectively. GADAb was found in $9 \%$ to $10 \%$ of patients in their 20 s or 30 s, less than $4 \%$ in patients in their 40 s, 50 s or 60 s, and in $5 \%$ of patients over 70 (Fig. 1).

\section{Clinical characteristics of type 2 diabetic patients according to presence of GADAb}

The mean ages of the patients with positive GADAb $(n=20)$ and negative GADAb $(n=442)$ were $52.3 \pm 14.1$ and $55.3 \pm 11.6$, respectively. There was no difference in age, age at the time of diagnosis of diabetes, or the duration of diabetes between GADAb-positive and GADAb-negative patients. Proportions of patients taking antihypertensive medication or 3-hydroxy3-methylglutaryl-coenzyme A (HMG-CoA) reductase inhibitor were not different in the groups. Three of 20 (15.0\%) GAD$\mathrm{Ab}$-positive patients required insulin treatment compared to 24 of 442 (5.4\%) GADAb-negative patients, a difference which was only marginally significant $(P=0.074)$.

BMI values were not statistically different between the two groups $\left(23.7 \pm 3.6 \mathrm{~kg} / \mathrm{m}^{2}\right.$ vs. $\left.25.2 \pm 3.6 \mathrm{~kg} / \mathrm{m}^{2}, P=0.101\right)$, although BMI tended to be lower in patients with positive GADAb. C-peptide levels were significantly lower in GADAb-positive patients than in GADAb-negative patients $(1.2 \pm 0.8 \mathrm{ng} / \mathrm{mL}$ vs. $2.0 \pm 1.2 \mathrm{ng} / \mathrm{mL}, P=0.004)$. The two groups did not differ with respect to waist circumference, waist-to-hip circumference ratio, systolic blood pressure, diastolic blood pressure, fasting insulin levels, $\mathrm{HbA1c}$, fasting glucose levels, or serum lipid profile (including total cholesterol, triglyceride, high density lipoprotein cholesterol [HDL-C], and low density lipoprotein cholesterol [LDL-C]). GADAb-positive and GADAb-negative patients had similar values of HOMA-insulin resistance
Table 1. Clinical characteristics of recently diagnosed type 2 diabetic patients according to the presence or absence of GADAb

\begin{tabular}{|c|c|c|c|}
\hline Characteristic & GADAb $(+)$ & GADAb (-) & $P$ value \\
\hline No. & 20 & 442 & \\
\hline Sex, M/F & $12 / 8$ & $248 / 194$ & 0.731 \\
\hline Age at study, yr & $52.3 \pm 14.1$ & $55.3 \pm 11.6$ & 0.253 \\
\hline Age at onset, yr & $50.0 \pm 14.4$ & $53.6 \pm 11.6$ & 0.180 \\
\hline Duration of diabetes, yr & $2.3 \pm 1.3$ & $1.7 \pm 1.6$ & 0.123 \\
\hline $\mathrm{BMI}, \mathrm{kg} / \mathrm{m}^{2}$ & $23.7 \pm 3.6$ & $25.2 \pm 3.6$ & 0.101 \\
\hline $\begin{array}{l}\text { Systolic blood pressure, } \\
\text { mm Hg }\end{array}$ & $120.5 \pm 10.1$ & $126.3 \pm 13.0$ & 0.063 \\
\hline $\begin{array}{l}\text { Diastolic blood pressure, } \\
\mathrm{mm} \mathrm{Hg}\end{array}$ & $70.0 \pm 6.1$ & $74.3 \pm 9.2$ & 0.051 \\
\hline Waist circumference, $\mathrm{cm}$ & $87.1 \pm 7.2$ & $86.5 \pm 8.7$ & 0.795 \\
\hline Waist-to-hip ratio & $0.91 \pm 0.03$ & $1.15 \pm 4.77$ & 0.846 \\
\hline $\begin{array}{l}\text { Fasting plasma C-peptide, } \\
\text { ng/mL }\end{array}$ & $1.2 \pm 0.8$ & $2.0 \pm 1.2$ & 0.004 \\
\hline $\begin{array}{l}\text { Fasting plasma insulin, } \\
\mu \mathrm{U} / \mathrm{mL}\end{array}$ & $9.6 \pm 3.9$ & $13.4 \pm 8.4$ & 0.055 \\
\hline HOMA-IR & $3.5 \pm 1.8$ & $4.5 \pm 3.8$ & 0.242 \\
\hline HOMA- $\beta$ cell function & $51.6 \pm 29.1$ & $83.4 \pm 82.8$ & 0.096 \\
\hline HbAlc, \% & $8.0 \pm 2.4$ & $7.5 \pm 1.6$ & 0.407 \\
\hline $\begin{array}{l}\text { Fasting plasma glucose, } \\
\text { mg/dL }\end{array}$ & $147.3 \pm 43.1$ & $135.8 \pm 41.3$ & 0.225 \\
\hline Total cholesterol, mg/dL & $178.8 \pm 43.1$ & $185.9 \pm 41.5$ & 0.449 \\
\hline Triglycerides, mg/dL & $124.8 \pm 47.0$ & $172.9 \pm 147.3$ & 0.146 \\
\hline HDL-C, mg/dL & $50.7 \pm 12.7$ & $47.8 \pm 12.7$ & 0.324 \\
\hline LDL-C, mg/dL & $107.9 \pm 36.2$ & $110.6 \pm 37.2$ & 0.756 \\
\hline $\begin{array}{l}\text { No. of patients using } \\
\text { insulin (\%) }\end{array}$ & $3(15.0)$ & $24(5.4)$ & 0.074 \\
\hline $\begin{array}{l}\text { No. of patients using } \\
\text { antidiabetic drugs (\%) }\end{array}$ & $8(40.0)$ & $124(28.1)$ & 0.247 \\
\hline $\begin{array}{l}\text { No. of patients using } \\
\text { antihypertensive drugs (\%) }\end{array}$ & $6(30.0)$ & $166(37.6)$ & 0.494 \\
\hline $\begin{array}{l}\text { No. of patients using } \\
\text { statins (\%) }\end{array}$ & $4(20.0)$ & $127(28.7)$ & 0.397 \\
\hline
\end{tabular}

Values are presented as mean \pm standard deviation or number (\%). GADAb, glutamic acid decarboxylase antibody; BMI, body mass index; HOMA-IR, homeostasis model assessment of insulin resistance; HDL-C, high density lipoprotein cholesterol; LDL-C, low density lipoprotein cholesterol; statins, HMG-CoA reductase inhibitors.

(IR) and HOMA $\beta$-cell function (Table 1).

According to the titer of GADAb, we divided the LADA patients into high- $(\geq 10 \mathrm{U} / \mathrm{mL})$ and low-titer $(<10 \mathrm{U} / \mathrm{mL})$ subgroups, which was a similar analytic approach as that used in a previous study [26]. C-peptide levels were higher in LADA 
Table 2. Clinical characteristics of LADA patients according to GADAb titer

\begin{tabular}{|c|c|c|c|}
\hline Characteristic & $\begin{array}{c}\text { Low titer } \\
(<10 \mathrm{U} / \mathrm{mL})\end{array}$ & $\begin{array}{l}\text { High titer } \\
(\geq 10 \mathrm{U} / \mathrm{mL})\end{array}$ & $P$ value \\
\hline No. & 14 & 6 & \\
\hline GADAb titer, $\mathrm{U} / \mathrm{mL}$ & $2.3 \pm 1.2$ & $233.9 \pm 436.2$ & 0.000 \\
\hline Age at study, yr & $52.2 \pm 14.1$ & $52.3 \pm 15.6$ & 0.968 \\
\hline Age at onset, yr & $50.1 \pm 14.2$ & $49.8 \pm 16.2$ & 0.968 \\
\hline Duration of diabetes, yr & $2.1 \pm 1.1$ & $2.5 \pm 1.9$ & 0.718 \\
\hline $\mathrm{BMI}, \mathrm{kg} / \mathrm{m}^{2}$ & $23.9 \pm 4.0$ & $23.4 \pm 3.1$ & 0.750 \\
\hline $\begin{array}{l}\text { Systolic blood pressure, } \\
\text { mm Hg }\end{array}$ & $119.3 \pm 9.0$ & $122.8 \pm 12.6$ & 0.494 \\
\hline $\begin{array}{l}\text { Diastolic blood pressure, } \\
\mathrm{mm} \mathrm{Hg}\end{array}$ & $68.3 \pm 4.2$ & $73.5 \pm 8.0$ & 0.083 \\
\hline Waist circumference, $\mathrm{cm}$ & $85.8 \pm 6.6$ & $90.5 \pm 8.4$ & 0.454 \\
\hline Waist-to-hip ratio & $0.90 \pm 0.03$ & $0.92 \pm 0.05$ & 0.240 \\
\hline $\begin{array}{l}\text { Fasting plasma } \\
\text { C-peptide, ng/mL }\end{array}$ & $1.54 \pm 0.68$ & $0.46 \pm 0.50$ & 0.002 \\
\hline $\begin{array}{l}\text { Fasting plasma insulin, } \\
\mu \mathrm{U} / \mathrm{mL}\end{array}$ & $10.3 \pm 4.4$ & $8.2 \pm 2.3$ & 0.416 \\
\hline HOMA-IR & $3.5 \pm 2.1$ & $3.4 \pm 1.3$ & 0.701 \\
\hline HOMA- $\beta$ cell function & $54.4 \pm 19.8$ & $45.5 \pm 45.1$ & 0.210 \\
\hline $\mathrm{HbA} 1 \mathrm{c}, \%$ & $7.5 \pm 1.7$ & $9.2 \pm 3.3$ & 0.239 \\
\hline $\begin{array}{l}\text { Fasting plasma glucose, } \\
\text { mg/dL }\end{array}$ & $135.4 \pm 25.4$ & $175.2 \pm 63.7$ & 0.207 \\
\hline Total cholesterol, mg/dL & $166.4 \pm 40.3$ & $207.5 \pm 37.9$ & 0.109 \\
\hline Triglycerides, mg/dL & $135.1 \pm 46.3$ & $100.7 \pm 42.8$ & 0.274 \\
\hline $\mathrm{HDL}-\mathrm{C}, \mathrm{mg} / \mathrm{dL}$ & $47.0 \pm 12.0$ & $59.3 \pm 10.7$ & 0.026 \\
\hline LDL-C, mg/dL & $99.4 \pm 11.9$ & $127.7 \pm 32.5$ & 0.041 \\
\hline $\begin{array}{l}\text { No. of patients using } \\
\text { insulin (\%) }\end{array}$ & $0(0)$ & $3(50.0)$ & 0.018 \\
\hline $\begin{array}{l}\text { No. of patients using } \\
\text { oral antidiabetic drugs (\%) }\end{array}$ & $7(50.0)$ & $1(16.7)$ & 0.325 \\
\hline $\begin{array}{l}\text { No. of patients using } \\
\text { antihypertensive drugs (\%) }\end{array}$ & $5(35.7)$ & $1(16.7)$ & 0.613 \\
\hline $\begin{array}{l}\text { No. of patients using } \\
\text { statins (\%) }\end{array}$ & $3(21.4)$ & $1(16.7)$ & 1.000 \\
\hline
\end{tabular}

Statistical significance was determined by Mann-Whitney $U$ test or Fisher's exact test.

Values are presented as mean \pm standard deviation or number (\%). LADA, latent autoimmune diabetes in adults; GADAb, glutamic acid decarboxylase antibody; BMI, body mass index; HOMA-IR, homeostasis model assessment of insulin resistance; HDL-C, high density lipoprotein cholesterol; LDL-C, low density lipoprotein cholesterol; statins, HMG-CoA reductase inhibitors.

patients with a low-titer of GADAb than in those with a hightiter of GADAb. The HDL-C and LDL-C concentrations were higher in the LADA patients with a high titer of GADAb than in those with a low titer of GADAb. The LADA patients with a high titer of GADAb were more likely to require insulin than those with a low titer of GADAb (Table 2).

\section{DISCUSSION}

Type 1A diabetes mellitus results from the autoimmune destruction of insulin-producing $\beta$-cells in pancreatic islets. ICA and GADAb are markers of autoimmunity and are detected in $70 \%$ to $80 \%$ of patients with type 1 diabetes [27]. LADA is defined as the initially non-insulin-requiring condition of diabetes with autoimmune markers of type 1 diabetes, such as ICA and GADAb. Progressive $\beta$-cell destruction by autoimmune mechanisms is considered as the main pathogenesis of LADA $[28,29]$. IA-2 antibody is detected in a high frequency at diagnosis in type 1 diabetic children, whereas the frequency is lower in LADA patients [30]. In addition, GADAb has a higher sensitivity compared with ICA $[9,17]$. Therefore, we used GADAb to identify cases with LADA in this study.

In previous studies performed in Korea, the prevalence of GADAb-positivity in type 2 diabetes was reported to be $1.7 \%$ to $12.6 \%$ [19-24]. In the current study, $4.3 \%$ of patients were positive for GADAb, which represents similar findings as those reported by Ko et al. [22], Oh et al. [24], and Lee et al. [31]. Most previous Korean studies selected patients who were non-obese or patients tested for GADAb who were under clinical suspicion of a diagnosis other than type 2 diabetes. In our study, we tested GADAb in all type 2 diabetic patients with a recent onset (within the past 5 years) regardless of their clinical characteristics at the time of presentation, which might help us avoid selection bias and therefore more accurately estimate the unbiased prevalence of LADA.

The prevalence of GADAb-positivity in this study was similar to the prevalence in Japanese studies [32,33]; however, it was lower than that reported in China [34] or Western countries $[7,17]$. The prevalence of LADA has been estimated in a number of studies (including large-scale studies) [7,35], revealing a wide range of variations from $2 \%$ to $20 \%$ (Table 3 ). The prevalence of LADA has been shown to vary even within the same country. In Swedish studies, the frequency of LADA ranged from $8 \%$ to $24 \%$. A wide range of variation in the prevalence of LADA within a country or across countries may depend on criteria for diagnosis, antibody assay methods, characteristics of the patients, and genetic susceptibility. 
Table 3. Prevalence of GADAb in adult patients with clinical features of type 2 diabetes

\begin{tabular}{|c|c|c|c|c|c|c|}
\hline Author & Country & Study type & Age & Participants (n) & Other inclusions & Prevalence \\
\hline Current study & Korea & Clinic referrals & $\geq 20$ & T2DM (462) & & $4.3 \%$ \\
\hline Park et al. [19] & Korea & Population-based & & New NIR (121) & & $1.7 \%$ \\
\hline Ko et al. [22] & Korea & Clinic referrals & & New NIR (245) & & $4.0 \%$ \\
\hline Kim et al. [23] & Korea & Clinic referrals & $\geq 25$ & T2DM (428) & $\begin{array}{l}\text { BMI } \\
\quad \leq 25\left(\mathrm{~kg} / \mathrm{m}^{2}\right)\end{array}$ & $12.6 \%$ \\
\hline Oh et al. [24] & Korea & Clinic referrals & & New NIR (267) & $\begin{array}{l}\text { Use of sulfonyl- } \\
\text { urea }\end{array}$ & $4.1 \%$ \\
\hline Lee et al. [31] & Korea & Clinic referrals & $\geq 25$ & T2DM $(9,250)$ & & $4.7 \%$ \\
\hline Bosi et al. [37] & Italy & Population-based & $>40$ & $(2,076)$ & & $\begin{array}{c}2.8 \% \text { in diabetic patients, } \\
1 \% \text { in normal controls }\end{array}$ \\
\hline Tuomi et al. [17] & Finland & Population-based & $28-83$ & All NIR $(1,122)$ & & $9.3 \%$ \\
\hline Turner et al. [7] & UK & $\begin{array}{l}\text { Representative pop- } \\
\text { ulation }\end{array}$ & $25-65$ & New NIR $(3,672)$ & Caucasian & $10.0 \%$ \\
\hline Ruige et al. [38] & Holland & Population sample & $50-74$ & $\begin{array}{l}\text { General population, } \\
\text { all known diabetics, } \\
\text { screened diabetics }(2,350)\end{array}$ & & $\begin{array}{l}0.7 \text { in normal controls, } 3.5 \% \\
\text { in known diabetics, } 0 \% \text { in } \\
\text { newly detected diabetics }\end{array}$ \\
\hline Niskanen et al. [9] & Finland & $\begin{array}{l}\text { General practitioner } \\
\text { referrals from de- } \\
\text { fined population }\end{array}$ & $45-64$ & New NIR (133) & & $9.0 \%$ \\
\hline Takeda et al. [32] & Japan & Clinic referrals & $>20$ & $(4,980)$ & & $3.8 \%$ \\
\hline Zinman et al. [35] & $\begin{array}{l}\text { North Ameri- } \\
\text { ca, Europe }\end{array}$ & Population-based & $30-75$ & New NIR $(4,134)$ & $\begin{array}{l}\text { FBG 7.0-10.0 } \\
(\mathrm{mmol} / \mathrm{L})\end{array}$ & $4.2 \%$ \\
\hline
\end{tabular}

GADAb, glutamic acid decarboxylase antibody; NIR, non-insulin-requiring diabetes; BMI, body mass index; T2DM, type 2 diabetes; FBG, fasting blood glucose.

In previous studies of Western countries, LADA patients have a lower BMI, more decreased insulin secretory capacity at diagnosis, and more rapid progression to insulin dependence than typical type 2 diabetes patients [7,9,17]. In the current study, the BMI of the patients with positive GADAb tended to be lower than that of the patients with negative GADAb, which was not a statistically significant difference. In addition, components of metabolic syndrome, such as hypertension, hypercholesterolemia, abdominal obesity, and fasting hyperglycemia, were evaluated in this study. No difference was seen between GADAb-positive and GADAb-negative patients with respect to the use of antihypertensive medication or HMG-CoA reductase inhibitors; serum levels of fasting glucose, triglycerides, total cholesterol, LDL-C, and HDL-C; or waist circumference and waist-to-hip circumference ratio. Patients with GADAb tended to have higher systolic and diastolic blood pressure than patients without GADAb. However, these differences were not statistically significant. These results were contrary to the findings of other studies. Tuomi et al. [17] report- ed that patients with GADAb had lower blood pressure, a lower level of triglycerides, and a lower waist-to-hip circumference ratio compared with patients without GADAb. The ADOPT study revealed that patients with positive GADAb had a higher level of serum HDL-C, lower serum triglyceride levels, and a lower prevalence of metabolic syndrome than patients with negative GADAb [35]. In another study performed in Caucasian populations, metabolic syndrome was more frequent in type 2 diabetes patients without GADAb than it was in LADA patients [16]. The mean BMI of our study patients was $25.3 \mathrm{~kg} / \mathrm{m}^{2}$, which is lower than that of Western studies $\left(27.5\right.$ to $\left.32 \mathrm{~kg} / \mathrm{m}^{2}\right)[7,17,35]$ and may explain different features related to metabolic syndrome among different ethnic groups. In this study, however, many patients without GADAb were treated with HMG-CoA reductase inhibitors, which might have contributed to attenuating the difference in lipid profiles according to the presence of GADAb. Nonetheless, even though there was no difference in the use of HMG-CoA reductase inhibitors between high- and low-GADAb titer groups, the HDL- 
$\mathrm{C}$ and LDL-C concentrations were lower in LADA patients with a low titer of GADAb than they were in those with high GADAb titers. The apparent absence of an association between LADA and the features of metabolic syndrome may be due to the small number of participants in our study. Therefore, a large-scale, nationwide study is warranted to examine the clinical characteristics related to metabolic syndrome in patients with LADA in Korea.

We observed that GADAb-positive patients had lower Cpeptide levels than GADAb-negative patients, which suggests that $\beta$-cell destruction by autoimmunity may elicit decreased insulin secretory capacity in patients with LADA [31]. In addition, patients who were positive for GADAb tended to use insulin more frequently than patients who were negative for GADAb. Furthermore, the LADA patients with a high titer of GADAb obviously needed more insulin therapy and had lower C-peptide levels than the LADA patients with a low titer of GADAb, which was consistent with the results of a previous study [17]. Because patients with LADA also exhibit insulin resistance like that in type 2 diabetic patients, they may require a different therapeutic approach than the usual type 2 diabetic patients. Sulfonylureas are generally not recommended as the first-line therapy for LADA because these drugs may bring about earlier insulin dependence [36]. As was shown in the present study, the clinical characteristics of LADA in Korea may be different from those in Western countries; it may be necessary to develop a therapeutic strategy unique to Korean patients.

In conclusion, we showed that the prevalence of LADA was $4.3 \%$ among recently diagnosed type 2 diabetic patients in Korea. The Korean LADA patients exhibited decreased insulin secretory capacity in terms of C-peptide level. Considering the unique pathogenetic mechanism of LADA, encompassing not only prominent insulin deficiency but also insulin resistance, it is mandatory to develop an effective therapy to reduce hyperglycemia and to halt the progressive beta-cell failure in these patients.

\section{CONFLICTS OF INTEREST}

No potential conflict of interest relevant to this article was reported.

\section{ACKNOWLEDGMENTS}

This study was supported by Grant 00-PJ3-PG6-GN07-001 from the Genome Research Center for Diabetes and Endocrine Disease, Ministry of Health \& Welfare, Republic of Korea.

\section{REFERENCES}

1. MacCuish AC, Irvine WJ, Barnes EW, Duncan LJ. Antibodies to pancreatic islet cells in insulin-dependent diabetics with coexistent autoimmune disease. Lancet 1974;2:1529-31.

2. Baekkeskov S, Aanstoot HJ, Christgau S, Reetz A, Solimena M, Cascalho M, Folli F, Richter-Olesen H, De Camilli P. Identification of the $64 \mathrm{~K}$ autoantigen in insulin-dependent diabetes as the GABA-synthesizing enzyme glutamic acid decarboxylase. Nature 1990;347:151-6.

3. American Diabetes Association. Diagnosis and classification of diabetes mellitus. Diabetes Care 2011;34 Suppl 1:S62-9.

4. Irvine WJ, McCallum CJ, Gray RS, Duncan LJ. Clinical and pathogenic significance of pancreatic-islet-cell antibodies in diabetics treated with oral hypoglycaemic agents. Lancet 1977; 1:1025-7.

5. Gottsater A, Landin-Olsson M, Fernlund P, Lernmark A, Sundkvist G. Beta-cell function in relation to islet cell antibodies during the first $3 \mathrm{yr}$ after clinical diagnosis of diabetes in type II diabetic patients. Diabetes Care 1993;16:902-10.

6. Tuomi T, Groop LC, Zimmet PZ, Rowley MJ, Knowles W, Mackay IR. Antibodies to glutamic acid decarboxylase reveal latent autoimmune diabetes mellitus in adults with a non-insulin-dependent onset of disease. Diabetes 1993;42:359-62.

7. Turner R, Stratton I, Horton V, Manley S, Zimmet P, Mackay IR, Shattock M, Bottazzo GF, Holman R. UKPDS 25: autoantibodies to islet-cell cytoplasm and glutamic acid decarboxylase for prediction of insulin requirement in type 2 diabetes. UK Prospective Diabetes Study Group. Lancet 1997;350:1288-93.

8. Zimmet PZ, Tuomi T, Mackay IR, Rowley MJ, Knowles W, Cohen M, Lang DA. Latent autoimmune diabetes mellitus in adults (LADA): the role of antibodies to glutamic acid decarboxylase in diagnosis and prediction of insulin dependency. Diabet Med 1994;11:299-303.

9. Niskanen LK, Tuomi T, Karjalainen J, Groop LC, Uusitupa MI. GAD antibodies in NIDDM. Ten-year follow-up from the diagnosis. Diabetes Care 1995;18:1557-65.

10. Groop L, Groop PH, Koskimies S. Relationship between B-cell function and HLA antigens in patients with type 2 (non-insulin-dependent) diabetes. Diabetologia 1986;29:757-60.

11. Juneja R, Palmer JP. Type 1 1/2 diabetes: myth or reality? Autoimmunity 1999;29:65-83. 
12. World Health Organization Department of Noncommunicable Disease Surveillance. Definition, diagnosis and classification of diabetes mellitus and its complications: report of a WHO consultation. Part 1, diagnosis and classification of diabetes mellitus. Geneva: World Health Organization; 1999. p59.

13. Fourlanos S, Perry C, Stein MS, Stankovich J, Harrison LC, Colman PG. A clinical screening tool identifies autoimmune diabetes in adults. Diabetes Care 2006;29:970-5.

14. Gale EA. Latent autoimmune diabetes in adults: a guide for the perplexed. Diabetologia 2005;48:2195-9.

15. Hosszufalusi N, Vatay A, Rajczy K, Prohaszka Z, Pozsonyi E, Horvath L, Grosz A, Gero L, Madacsy L, Romics L, Karadi I, Fust G, Panczel P. Similar genetic features and different islet cell autoantibody pattern of latent autoimmune diabetes in adults (LADA) compared with adult-onset type 1 diabetes with rapid progression. Diabetes Care 2003;26:452-7.

16. Hawa MI, Thivolet C, Mauricio D, Alemanno I, Cipponeri E, Collier D, Hunter S, Buzzetti R, de Leiva A, Pozzilli P, Leslie RD; Action LADA Group. Metabolic syndrome and autoimmune diabetes: action LADA 3. Diabetes Care 2009;32:160-4.

17. Tuomi T, Carlsson A, Li H, Isomaa B, Miettinen A, Nilsson A, Nissen M, Ehrnstrom BO, Forsen B, Snickars B, Lahti K, Forsblom C, Saloranta C, Taskinen MR, Groop LC. Clinical and genetic characteristics of type 2 diabetes with and without GAD antibodies. Diabetes 1999;48:150-7.

18. Cervin C, Lyssenko V, Bakhtadze E, Lindholm E, Nilsson P, Tuomi T, Cilio CM, Groop L. Genetic similarities between latent autoimmune diabetes in adults, type 1 diabetes, and type 2 diabetes. Diabetes 2008;57:1433-7.

19. Park Y, Lee H, Koh CS, Min H, Rowley M, Mackay IR, Zimmet P, McCarthy B, McCanlies E, Dorman J, Trucco M. The low prevalence of immunogenetic markers in Korean adult-onset IDDM patients. Diabetes Care 1996;19:241-5.

20. Kim KA, Ahn KJ, Chung JH, Min YK, Lee MK, Oh PS, Jin DK, Kim BT, Park HJ, Kim KW, Lee MS. Combined measurements of anti-ICA512 and anti-GAD antibodies in insulin-dependent diabetes mellitus and slowly progressive insulin-dependent diabetes mellitus in Korea. J Korean Diabetes Assoc 1998;22: 484-5.

21. Lee HH, Shin YG, Kim HS, Kim CY, Jeong YS, Kim HS, Park DW, Yoon KJ, Chung CH. Measurement of anti-GAD antibody by EIA and RIA methods in Korean diabetic patients: study for pathogenesis of slowly progressive IDDM. J Korean Diabetes Assoc 1997;21:234-5.

22. Ko KS, Hong SK, Lee KU, Kim NH, Choi DS, Ihm SH, Park
SW, Kim CH, Byun DW, Suh KI, Chang HC, Rhee BD. The frequency of ICA and anti-GAD antibody in Korean IDDM and NIDDM patients. J Korean Diabetes Assoc 1998;22:313-4.

23. Kim CS, Park JA, Cho MH, Park JS, Nam JY, Kim DM, Ahn CW, Cha BS, Lim SK, Kim KR, Lee HC. The frequency of antiGAD antibody in non-obese, adult-onset type 2 diabetes in Korea and clinical and biological characteristics according to anti-GAD antibody. J Korean Diabetes Assoc 2004;22:66-74.

24. Oh JH, Yoon JS, Won KC, Lee HW. Antibodies to GAD and ICA in type $2 \mathrm{DM}$ with secondary failure of oral hypoglycemic therapy. J Korean Diabetes Assoc 2007;31:402-9.

25. Matthews DR, Hosker JP, Rudenski AS, Naylor BA, Treacher DF, Turner RC. Homeostasis model assessment: insulin resistance and beta-cell function from fasting plasma glucose and insulin concentrations in man. Diabetologia 1985;28:412-9.

26. Kasuga A, Maruyama T, Nakamoto S, Ozawa Y, Suzuki Y, Saruta T. High-titer autoantibodies against glutamic acid decarboxylase plus autoantibodies against insulin and IA-2 predicts insulin requirement in adult diabetic patients. J Autoimmun 1999;12:131-5.

27. Riley WJ, Maclaren NK, Krischer J, Spillar RP, Silverstein JH, Schatz DA, Schwartz S, Malone J, Shah S, Vadheim C, Rotter JI. A prospective study of the development of diabetes in relatives of patients with insulin-dependent diabetes. $\mathrm{N}$ Engl J Med 1990;323:1167-72.

28. Pozzilli P, Di Mario U. Autoimmune diabetes not requiring insulin at diagnosis (latent autoimmune diabetes of the adult): definition, characterization, and potential prevention. Diabetes Care 2001;24:1460-7.

29. Fourlanos S, Dotta F, Greenbaum CJ, Palmer JP, Rolandsson O, Colman PG, Harrison LC. Latent autoimmune diabetes in adults (LADA) should be less latent. Diabetologia 2005;48: 2206-12.

30. Naik RG, Palmer JP. Latent autoimmune diabetes in adults (LADA). Rev Endocr Metab Disord 2003;4:233-41.

31. Lee SA, Kim EY, Kim EH, Jeong JY, Jeong EH, Kim DW, Cho EH, Koh EH, Joong MS, Park Y, Lee KU. Anti-GAD antibody in patients with adult-onset diabetes in Korea. J Korean Diabetes Assoc 2009;33:16-23.

32. Takeda H, Kawasaki E, Shimizu I, Konoue E, Fujiyama M, Murao S, Tanaka K, Mori K, Tarumi Y, Seto I, Fujii Y, Kato K, Kondo S, Takada Y, Kitsuki N, Kaino Y, Kida K, Hashimoto N, Yamane Y, Yamawaki T, Onuma H, Nishimiya T, Osawa $\mathrm{H}$, Saito Y, Makino H; Ehime Study. Clinical, autoimmune, and genetic characteristics of adult-onset diabetic patients with 
GAD autoantibodies in Japan (Ehime Study). Diabetes Care 2002;25:995-1001.

33. Fukui M, Nakano K, Shigeta H, Yoshimori K, Fujii M, Kitagawa Y, Mori H, Kajiyama S, Nakamura N, Abe N, Obayashi H, Fukui I, Ohta K, Ohta M, Kondo M. Antibodies to glutamic acid decarboxylase in Japanese diabetic patients with secondary failure of oral hypoglycaemic therapy. Diabet Med 1997;14: 148-52.

34. Thai AC, Ng WY, Loke KY, Lee WR, Lui KF, Cheah JS. AntiGAD antibodies in Chinese patients with youth and adult-onset IDDM and NIDDM. Diabetologia 1997;40:1425-30.

35. Zinman B, Kahn SE, Haffner SM, O’Neill MC, Heise MA, Freed MI; ADOPT Study Group. Phenotypic characteristics of GAD antibody-positive recently diagnosed patients with type 2 dia- betes in North America and Europe. Diabetes 2004;53:3193200.

36. Brophy S, Brunt H, Davies H, Mannan S, Williams R. Interventions for latent autoimmune diabetes (LADA) in adults. Cochrane Database Syst Rev 2007;(3):CD006165.

37. Bosi EP, Garancini MP, Poggiali F, Bonifacio E, Gallus G. Low prevalence of islet autoimmunity in adult diabetes and low predictive value of islet autoantibodies in the general adult population of northern Italy. Diabetologia 1999;42:840-4.

38. Ruige JB, Batstra MR, Aanstoot HJ, Bouter LM, Bruining GJ, De Neeling JN, Heine RJ. Low prevalence of antibodies to GAD65 in a 50- to 74-year-old general Dutch population. The Hoorn Study. Diabetes Care 1997;20:1108-10. 